\title{
On the Symbol Concept of the Vedic Ritualists
}

\author{
ASKO PARPOLA
}

In his methodologically remarkable studies of the Ndembu ritual, Victor $\mathrm{W}$. Turner has gained important insights from the native terminology and exegesis of this Zambian people ${ }^{1}$. Naturally, the said materials are most relevant for the analysis of the Ndembu ritual. But, as the wide acknowledgement of Turner's work ${ }^{2}$ concretely shows, they are of considerable interest from the crosscultural perspective as well.

Different peoples have in their cultural and linguistic systems created individual conceptual categories which best fit their varying needs and surroundings, thus defining and interpreting the world in different ways ${ }^{3}$. While developing universal theories it is useful to take into account as many as possible independent systems of classification, for they can open up new perspectives and refine prevalent concepts. A striking example is supplied by the ancient Indian grammarians who, in spite of their exclusive preoccupation with Sanskrit, have given a lot of stimulation to modern general linguistics ${ }^{4}$.

The aim of the present paper is to contribute to the general study of the "ritual symbol", "the smallest unit of ritual which still retains the specific properties of ritual behavior" 5 , by drawing attention to, and sketching in basic outline, some central concepts held in this regard by the Vedic ritualists ${ }^{6}$.

The Vedic Brāhmana texts, composed around 1000-600 B.C., expound the esoteric meaning of the sacrifices which at the time were at the very centre of the cultural activity in the heart of North India. They are complemented by the slightly later Śrauta and Grihya Sūtras (ca. 700-200 B.C.), in which this extremely complicated ritual is systematically described ${ }^{7}$. The import-

1 Cf. especially Turner $1967,19 \mathrm{ff}$., $48 \mathrm{ff}$; 1969, $1 \mathrm{ff}$.

${ }^{2}$ Cf. e.g. Middleton 507.

${ }^{3}$ Cf. e.g. Werner $537 \mathrm{ff}$.

${ }^{4}$ Cf. Collinder $1 \mathrm{ff}$.; Staal XI ff.

5 Turner 1967,19 . Since the religious ritual is a communication system, its minimal unit could be called "sign" in accordance with the general theory of semiotics, "symbol" being just one of the subclasses of "sign", cf. Sebeok $244 \mathrm{ff}$. In the widely adopted ter- minology of Pike, $54 \mathrm{ff}$, the basic unit of any purposeful human behaviour is "eme".

6 The reader who wants to pursue the theme further is referred above all to the studies of Oldenberg 1919, $1 \mathrm{ff}$; Schayer 1925, $259 \mathrm{ff}$; and to the works of Gonda cited in the bibliography.

${ }^{7}$ For the Vedic texts cf. Gonda 1975, $1 \mathrm{ff}$; $1977,465 \mathrm{ff}$. For a synopsis of the Vedic ritual, cf. Gonda 1960, $104 \mathrm{ff}$, and for a more detailed account, Hillebrandt $1 \mathrm{ff}$. 
ance of the vast, homogenous, spontaneous and direct documentation thereby supplied for the general study of the religious ritual was fully realized by Henri Hubert and Marcel Mauss: they took it as the basic foundation of their classic study of the nature and function of the sacrifice ${ }^{8}$.

By about 1000 B.C., when the redaction of the Rgveda, the oldest Indian text known to us, was completed, a fundamental change in the religious attitude of the Vedic Aryans had already taken place. This happened most probably as a result of their assimilation with the earlier inhabitants of their new domain in India, the Dāsas ${ }^{9}$. Submission to almighty gods, who are worshipped with reverence and honoured with sacrifices in the old hymns of the Rgveda, had given way before a new kind of ritual, mechanistic and magical in its character. The sacrifice now enabled man to control the universe independently of the gods, who were largely reduced to the subordinate position of powers that could be manipulated at his will by an expert ritualist ${ }^{10}$.

As told in innumerable myths in the Brāhmana texts, it is the sacrifice that the gods have to thank for their exalted position ${ }^{11}$. The very creation of the world was the primeval sacrifice ${ }^{12}$. Sacrifice in its various forms not only is able to grant man all his wishes but to redeem him from death ${ }^{13}$. It also supports the entire universe, since "this all indeed results from [or: corresponds to, follows: anu] the sacrifice" (ŚB 3,6,3,1). Thus, for instance, the Śatapatha-Brāhmana declares $(2,3,1,5)$ : "And when he offers in the morning before sun-rise, then he produces that (sun-child) and, having become a light, it rises shining. But, assuredly, it would not rise, were he not to make that offering: this is why he performs that offering." 14

Although the Vedic ritual in its classical form as represented by the Brāhmana texts is not "magic" in the sociological sense of the word, since it is not directed against the society and its order ${ }^{15}$, the principle underlying the Vedic ritual is the basic law of magic: similia similibus ${ }^{16}$. Magical equations, which are the most characteristic feature of the Brāhmana texts, are established between the controlling ritual and the earthly, cosmic or mythical phenomena to be controlled ${ }^{17}$. The identifications are exploited by the manipulation of the ritual symbols. The Brāhmana texts consistently

8 Cf. Hubert 7 f., 19.

${ }^{9}$ Cf. Parpola 1976, $21 \mathrm{ff}$.

10 Cf. Gonda 1960, $108 \mathrm{ff}$, 105.

11 Cf. Lévi $41 \mathrm{ff}$.

12 Cf. ib. $13 \mathrm{ff}$.

13 Cf. Gonda 1975, 339 f.; Oldenberg 1919, $149 \mathrm{ff}$.

${ }^{14}$ The Vedic texts are generally quoted in standard translations (the SB in Eggeling's version, etc., cf. the bibliography), but in a few cases I have taken the liberty of making slight modifications, such as e.g. adding the
Sanskrit text in parentheses. Some translations, notably those of the MS and the KS, are my own.

15 Cf. Gonda 1965, 26; Durkheim 42 ff.; Diehl $13 \mathrm{ff}$.

${ }_{16}$ Cf. Gonda 1960, 177; Frazer 14 ff.

17 The equations are often expressly considered at three levels (e.g. in SB $10,2,6,16$ ), adhidevatam "with regard to the deities", adhyätmam "with regard to self", and adhiyajñam "with regard to the sacrifice". Cf. Oldenberg 1919, $57 \mathrm{f}$; S Schayer 1925, $286 \mathrm{f}$. 
emphasize that knowledge of the secret identity gives the knower power over the entities concerned. These magic identifications are the central object of the "pre-scientific science" (as it has been aptly called by Hermann Oldenberg) of the Vedic ritualists. It is the nature of these equations on which our attention shall be focused in the following ${ }^{18}$.

In their earliest accessible form the ritualistic identifications are found in the yajus formulae. These are generally muttered by the adhvaryu, the chief of the priests responsible for the actual sacrificial operations. Characteristically, they are not, as a rule, addressed to gods but to sacrificial offerings or utensils ${ }^{19}$. Not infrequently the yajus is twofold, consisting, first, of the name or epithet of the object, which reveals its secret nature, and, second, of a request activating the inherent power. The sacrificial fire, for instance, is addressed with this formula (cf. ĀpŚS 3,7,6): "Guardian of life art thou, o Agni; guard my life!" (TS 1,1,13i) ${ }^{20}$. It is apparent from this that a thing which is or represents a certain power is expected to give or diffuse $\mathrm{it}^{21}$.

In the explanatory prose passages attached to the yajus formulae or to other liturgical elements, that is, in the brähmanas in the more restricted sense of the word ${ }^{22}$, the identifications are usually stated with an almost mathematical brevity. A nominal sentence may consist of nothing else but the words for the two entities thus equated. But it is also usual to add an emphatic particle, such as vai, eva or $v \bar{a} v a$, after the more important part, the predicate noun, which occupies the stressed position at the beginning of the sentence, as it does in the yajus formulae. For instance, brahma krṣnăjinam "the black (antelope's) hide (is) Brahma" (TS 5,1,10,4); asau (scil. dyauh) krṣnājinam "the black (antelope's) hide (is) yonder (sky)" (KS 19,4; KapS 30,2); iyam (scil. prthivī) vai krṣnäjinam "the black (antelope's) hide verily (is) this (earth)" (TS 5,1,4,3; SB 6,4,1,9) ${ }^{23}$. Emphasis can also be given by adding a relative and a correlative particle in front of the two parts (yad ...tad ... "it is the ... that is ..."), or by other means ${ }^{24}$.

While translating such nominal sentences it is customary to add the copula ("is" or "are") ${ }^{25}$. This is entirely justified by the express use of the verb as- 'to be' in parallel equations occurring in yajus formulae and in mythical narratives (cf. e.g. eșa ha vāva samvatsarah prajāpatir àsa "Verily, Prajāpati was this year" in JB 3,375) ${ }^{26}$. But what is actually implied?

${ }^{18}$ For the identifications, cf. especially Oldenberg 1919, $110 \mathrm{ff}$.; Schayer 1925, $267 \mathrm{ff}$; Mylius 1968, $267 \mathrm{ff}$; 1976, $145 \mathrm{ff}$.; Gonda $1975,372 \mathrm{ff}$.

${ }^{19}$ Cf. Gonda 1975, $332 \mathrm{ff}$.

${ }^{20}$ Cf. Oldenberg 1917, 2 ff.; Gonda 1975, $332 \mathrm{ff}$.

${ }^{21}$ Cf. Gonda 1957, 32, $58 \mathrm{ff}$.

${ }_{22}$ Cf. ib. $340 \mathrm{ff}$.

${ }^{23}$ The best classified collection of equations in the Brāhmana texts is Vishva Bandhu $1 \mathrm{ff}$. (in Sanskrit only); a representative collection from the Maitrāyaṇi Saṃhitā (in German) is given by Schroeder $128 \mathrm{ff}$. For a content analysis cf. Mylius 1968, $267 \mathrm{ff}$; 1976, $145 \mathrm{ff}$.

${ }^{24}$ For a linguistic analysis of the nominal sentences cf. Gren-Eklund, Gunilla, $1 \mathrm{ff}$.

${ }^{25} \mathrm{Cf}$. ib. $15 \mathrm{ff}$.

${ }^{26}$ Cf. JB 2,393 prajāpatir eva samvatsarah "the year (is) Prajāpati". 
Should the verb "to be" be taken in the sense of literal identity? Or should one rather replace it by expressions such as "is a kind of", "stands for", "represents", "symbolizes"? I do not think that a single answer is admissible. It is a short step from symbolization to identification, and this makes it often difficult to find out what has been in the mind of the ancient ritualists $^{27}$. It is pertinent to remember that the Christian theologians have not been able to agree whether the bread and wine of the holy communion only symbolize or in actual fact are the body and blood of Jesus ${ }^{28}$.

In the Vedic religion the temporal factor has to be taken into consideration in this connection. By the close of the seventh century B.C., approximately, the concept of individuality started being abandoned: one was recognized in all and all in one ${ }^{29}$. The development of this pantheistic world view is intimately connected with the process of "internalization" or "mentalization" of the ritual. In the pränāgnihotra sacrifice, the concrete ritual acts are replaced by corresponding psychic acts taking place in the mind of the sacrificer ${ }^{30}$. This leads to the change of the kärmamärga into the jñänamärga, where the mere knowledge of the magical identities is sufficient: ritual technology becomes contemplative mysticism ${ }^{31}$.

The exact sense of the magic equations in the Brāhmana texts can be best studied by analysing parallel expressions. Thus it can be noted that instead of identifications, comparisons formed with the particle yatha or iva "as, like" can occur. The expression máma iva hí prajäpatih "for Prajāpåti is like the mind" (TS $2,5,11,5$ ) is exactly paralleled by the straight identification mano hi prajāpatih "for the Prajāpati is the mind" (SVidhB 1,1,1)

A term used for the other component of the equation is prati-má, literally "counter-measure" and more freely "copy, image, symbol". Let us take for an example the equation of the creator god Prajāpati with the sacrificial year. This magic identity is usually expressed in the Brāhmana texts with a nominal sentence of the usual kind ${ }^{26}$. But in SB 11,1,6,13 the year is said to be the pratima of Prajāpati. The text runs as follows: "Prajāpati bethought himself, 'Verily, I have created here a counterpart of myself, to wit, the year'; whence they say, 'Prajāpati is the year'; for he created it to be a counterpart of himself: inasmuch as samvatsara 'year' as well as Prajāpati consist of four syllables, thereby it [i.e. the year] is a counterpart of him." 33

One of the best clues to the meaning that the Vedic ritualists themselves attached to the identifications is supplied by the term rupa ${ }^{34}$. This term

27 Cf. Schroeder $127 \mathrm{ff}$; Oldenberg 1919 , $120 \mathrm{ff}$; also O'Flaherty, Wendy, 34.

${ }_{28}$ Cf. Oldenberg 1915, 18.

${ }^{29}$ Cf. Schroeder 130; Oldenberg 1915, $35 \mathrm{ff}$.

30 Cf. Bodewitz $211 \mathrm{ff}$.

31 Cf. Schayer 1925 a, 61.

${ }^{32}$ Cf. Oldenberg 1919, 115; Schayer 1925, 299 (: upamā).
33 Cf. Oldenberg 1919, $114 \mathrm{f}$.; Schayer 1925 , 275; Silburn, Lilian, 50.

34 For the term rüpa cf. especially Oldenberg 1919, 102 ff. , 114; Schayer 1925, 276; Gonda 1957, 97 ff.; Silburn, Lilian, 58f., 84 f. 
forms an exact counterpart to the identifications in sentences like the following. On the one hand the texts say brahma krṣnajinam "the black (antelope's) hide (is) the brahma" (TS 5,1,10,4), on the other etad vai brahmaṇo rüpam yat krṣnājinam (KS 19,4) or brahmana [ ${ }^{\circ}$ no vā TB] etad rüpam yat krṣnājinam (TS 5,4,4,4; TB 2,7,1,4) "the black (antelope's) hide (is) a rüpa of the brahma". There seems to be no real difference in meaning between these two kinds of expression ${ }^{35}$.

In contexts like the above one, the word rüpa is translated as "Erscheinungsform" or "Gestalt" by Oldenberg", as "form" or "type" by Eggeling ${ }^{36}$, as "characteristic mark" or "feature" or "nature" by Caland ${ }^{37}$, as "manifestation" or "representation" by Gonda ${ }^{34}$, and as "symbol" by Keith $^{38}$, Renou ${ }^{39}$ and Silburn ${ }^{34}$. Monier-Williams's dictionary ${ }^{40}$ records among others the following meanings of this word as being valid for the Vedic language: "any outward appearance or phenomenon or colour, form, shape, figure; nature, character, peculiarity, feature, mark, sign, symptom". Macdonell's dictionary ${ }^{41}$ gives in addition the meanings "likeness, image, reflexion; indication, token, symbol, manifestation". The central meaning is "form, shape". In the classical Sanskrit, the derivative rüpa-ka has, as an adjective, the signification "designating figuratively", and as a technical term of the poetics, "metaphor" as well as "drama". The corresponding denominative verb rüpayati of the post-Vedic language means "to give form to, represent, act on the stage, represent in pantomime, notify by a gesture"'40-41.

It will be clear from the following passages that the word rüpa is used in the Brāhmaṇa texts in a meaning fairly close to our "symbol". In the Aitareya-Brāhmana $(2,1,6)$ we read:

"He who desires nutritious food and he who desires prosperity should make his sacrificial post of bilva wood. Year by year, the bilva tree is fruitful; therefore it is a rüpa of nutritious food. Up to the root, it is beset all along with branches; therefore it is (a rīpa) of prosperity. He prospers in offspring and cattle who knowing thus makes the sacrificial post of bilva wood. Now as to (his using) bilva wood, they say about bilva that '(it is) light'; a light he becomes among his own people, the chief of his own people he becomes, who knows thus." 42

The archaic mahàvrata rite is connected with a turning point of the sun's course and marks the end of the old year and the beginning of the new. It is celebrated with many characteristic ritual acts. One is described in the Katha-Samphitā (34,5:39,3-6), one of our oldest sources here, as follows: "An Āryan and a Súdra [i.e. a member of the darkhued servile class] fight

${ }^{35}$ Cf. Oldenberg 1919,108 n. 4.

${ }^{36}$ Cf. Eggeling 3, 360 (on SंB 7,3,2,16); 5,125 (on SB 11,7,4,4).

37 Cf. Caland 1931, 83 (on PB 5,5,21), 127 (on PB 6,9,25).
${ }^{38}$ Cf. Keith 135 (on AB 2,1,6).
${ }^{39}$ Cf. Renou 1954, 73.
${ }^{40}$ Cf. Monier-Williams 885 f.
${ }^{41}$ Cf. Macdonell 257.
${ }^{42}$ Cf. Keith 134; Gonda 1957, 97. 
for a hide by pulling it in different directions. The gods and demons, forsooth, fought for the sun by pulling it in different directions. The gods won it. He makes the Aryan class [literally, the Aryan colour] to win; it is himself that he makes to win. The Aryan should be inside the sacred space, the Südra outside the sacred space. The hide should be white (and) circular, (as) a rüpa of the sun [śvetam carma parimandalam syād, àdityasya rūpam]." In the corresponding passage of the Pañcavimśa-Brāhmana $(5,5,14-17)$ based on the $\mathrm{KS}^{43}$ the last sentence reads: "The hide is circular; it is the sun whose rüpa is thereby made [in this hide (comm.)] [parimandalam carma bhavaty, àdityasya tad rūpam kriyate, scil. asmin carmani]". The mediaeval commentator, Sāyana, explains: "It was namely for the sun that the fight of the gods was made in ancient times; this has been told [scil. above in the text]. For that very reason this hide is a counterfeit of the sun." The gloss here is prati-rüpaka, literally, "having counterform".

Some other passages are very instructive with regard to the instrumental function of the rupa. This function is, of course, one of the basic characteristics of ritual symbols in general ${ }^{44}$. When the sacred fires are established a second time (which may happen, for instance, if the year following the first establishment has been unlucky, if one has lost a son, etc., cf. ĀpŚS $5,26,3)$, the gifts to the priests include, according to MS 1,7,2: 110,12 ff., a cloth that has been mended by sewing it up again, an ox that has been let loose a second time, and a chariot that has been repaired again. This is explained in the text as follows: "Verily, these (gifts) are ruppas of the renewed foundation (of the sacred fires) [etâni vai punarādheyasya rüpāni]. He obtains it after having reached its rüpas [rüpāny evāsyāptvāvarunddhe]." The parallel passage in KS 8,15: $98,19 \mathrm{ff}$. has for the last sentence this: "It is by means of the rūpas that he perfects that (renewed foundation of the fires) [rüpair evainat samardhayati]."

The here used verb sam-rdh- which in the causative has the meaning "to perfect, make complete", occurs even elsewhere in connection with the word rüpa. Commenting upon the relation between the ritual formula and the corresponding sacrificial act which is somehow illustrated by the formula, the Aitareya-Brăhmana $(1,4,9)$ says: "That, indeed, is perfect in the sacrifice which is perfect in rūpa [or: abundantly furnished with rüpa] [etad vai yajñasya samrddham yad rüpasamrddham]." ${ }^{45}$ Similarly it is said a little later in the same text $(1,19,6)$ : "what in the sacrifice is con-formable (to it) that is perfect [yad yajñe 'bhirüpam tat samrddham]".

The term sam-rddha "completed, perfect" is nearly synonymous with sarva "whole, complete, entire". In SB 5,1,4,5 the verb samardhayati "makes to attain or succeed fully, completes, perfects" is followed by the

${ }^{43}$ Cf. Parpola 1968, 81, $85 \mathrm{ff} ., 93 \mathrm{f}$.

${ }^{44}$ Cf. e.g. Turner 1967, 32, 37; Diehl $22 \mathrm{ff}$.

${ }_{45}$ Cf. Oldenberg 1919, 245. 
synonymous expression krtsnam karoti "makes (the object) whole" ${ }^{46}$. The word samrddha qualifies the term rüpa in SB 6,4,4,17, where the plants are said to have their "perfect form" when they are blossoming and fullberried. Similarly in SB 6,5,1,10 the woman has her "perfect form" when she is fair-knotted, fair-braided, fair-locked; by pronouncing the formula where the goddess Sinivali is addressed as such a woman with beautiful hair, he thus makes her perfect (smardhayaty evainām etat $)^{47}$. The Jaiminiya-Brähmana $(3,115)$ explains that water is placed close by while the chanter priests sing the mahānämnì stanzas in order to make the sacrificial song complete (sämnas sarvatvāya), "for verily, water is the complete manifestation [sarvam rüpam] of the mahänāmnī stanzas"48.

The importance placed on the abundance of symbolic manifestation apparent from the above quotations is connected with the central position occupied by the idea of integrity and wholeness in the Vedic thought. It is the state of not being defective or ill: Sanskrit sarva is etymologically the same word as Latin salvus ${ }^{49}$. The Chändogya-Upanișad $(7,26,2)$ states that "he who (truly) sees does not see death, nor illness nor any distress; he who (truly) sees sees the All [i.e., wholeness, completeness, integrity], he reaches [or: obtains] the All in all respects [or: entirely]." ${ }_{50}$ Idam sarvam "all this" means "the complete universe", which is very frequently identified with Prajāpati or Brahma ${ }^{50}$. In SB 10,4,3,3-8 the gods are trying to attain immortality by performing sacrificial rites. They do not, however, succeed until Prajāpati intervenes and says to them: "Ye do not lay down [or: put on me] all my forms [na vai me sarvāni rūpāny upadhattha]; ye either make (me) too large or leave (me) defective: therefore ye do not become immortal." The sacrifice is the counterpart of Prajāpati; it is the counterpart of the universe or "this all", which means "integrity", "being whole" and thus "being safe from illness and death", i.e. "immortality"; and this sacrifice-Prajāpati-immortality cannot be reached except by making it complete, by perfecting $i^{51}$.

Further insight into the nature of the rüpa concept and Prajāpati's completeness is provided by two passages of the Satapatha-Brāhmana. In 6,5,3,6-7 we read: "He makes these (bricks) from (clay) prepared with prayer, the other from (clay) prepared without prayer; for these are defined, the others undefined; these are limited (in number), the others unlimited. 7. That Agni [i.e., the fire altar built of these bricks] is Prajāpati; but Prajāpati is both of this, defined [nirukta] and undefined [anirukta], limited [parimita] and unlimited [aparimita]: thus when he makes (bricks) from (clay) prepared with prayer, he thereby makes up that form [rūpa] of his [i.e. Prajāpati's] which is defined and limited; and when he makes up

\footnotetext{
46 Cf. Gonda 1955, 55.

47 Cf. Oldenberg 1919, 106 n. 2.

48 Cf. Gonda 1957, 99.
}

49 Cf. id. 1955, 67f.

50 Cf. ib. $62 \mathrm{f}$.

51 Cf. Silburn, Lilian, $58 \mathrm{f}$. 
them from (clay) prepared without prayer, he thereby makes up that form of his which is undefined and unlimited. Verily, then, whosoever knowing this does it in this way, makes up the whole and complete Prajāpati." The passage 7,2,4,29-30 is otherwise identical, but the actions done with and without a prayer differ: instead of making bricks, one yokes oxen, ploughs furrows, etc. Moreover, there is an important addition at the end: "The outer forms [bāhyyāni rüpāni $]$ are defined, and the inner ones [antarāni] are undefined; and Agni is the same as an animal: hence the outer forms of the animal are defined, the inner ones undefined."

The term nir-ukta, which in the above quoted translation by J. Eggeling has been rendered "defined", literally means "expressly stated", "clearly or distinctly uttered". In the Vedic ritual it refers to hymns and formulae recited in a loud voice (uccaih); or to sacrificial songs sung according to the original, intelligible syllables; or to formulae which contain (to use a term of the slightly later Śrautasūtra period) a linga, that is, a "characteristic element" such as the name of a specific deity. Nir-ukta, in other words, explicitly states the meaning. It thus corresponds to another important term often used in the Brähmanas, namely, praty-akșa "that which is before the eyes, visible, perceptible, manifest, open, plain".

The opposite term a-nir-ukta, literally "that which is not expressly stated or distinctly uttered", refers in the ritual to "inaudibly, silently" (upāmśu, tüṣnim) or "mentally" (manasā) uttered stanzas and formulae; or to songs based on unintelligible syllables substituted for the original, meaningful text; or to formulae without a linga. Anirukta corresponds to the term paro-' $k s a$ "that which is beyond the sight, invisible, inperceivable, cryptic, mystical".

Nirukta is thus everything that has a definite outline or shape or structure, while anirukta goes beyond all such defined things and is needed to complete and perfect them. For the whole (sarva) transcends all (viśva), its elements. According to $\mathrm{AB} 2,31,5$, there must be, at the end of the audible recitations or the explicit lauds, a silent praise (tüsñimm-śamsa), which perfects (sam-sthā-) the sacrifice ${ }^{52}$.

The terms praty-akssa and paro-'ksa occur also in the magical equations. A noteworthy passage is PB 22,10,3-4: "What presents itself in a visible way to men (presents itself) in a cryptical way to the gods, and what (presents itself) in a cryptical way to men (presents itself) in a visible way to the gods. 4. The viśvajit (rite) is, in a cryptical way, the (mahā)vrata (rite); in a visible way he, by means of this (rite) obtains food [vrata]." ${ }_{53}$ The here stated opposition is resorted to when secret connections are established through etymologies which do not entirely fit the observable facts. Thus the Bṛhad-Āranyaka-Upanișad $(4,2,2)$ says: "Indha 'kindler' by name is

\footnotetext{
${ }^{52}$ For this discussion of the terms nirukta, anirukta, etc., cf. Renou 1954, $68 \mathrm{ff}$.

${ }^{53}$ Cf. Caland 579.
} 
this person here in the right eye. Him, verily, who is that Indha people call Indra, cryptically, for the gods are fond of the cryptic, as it were, and dislike the evident." It can be seen from this that the secret, speculative knowledge was highly appreciated, and the value of the empirical knowledge correspondingly underestimated ${ }^{54}$.

The terms pratyaksa and paro-'kșa refer to the eye (aksa) and the sight. In the philosophy of the Upanișads (cf. e.g. $B \bar{A} U 3,2,5 ; 3,9,20$ ), the ruppa or "form, shape" is the object of the sight, just as the sound is the object of hearing. Already the Rgveda-Samhita $(6,47,18)$ says of Indra that "this is his rüpa for looking at [tád asya rüpám praticákșanāya]". In $\mathbb{R S ~ 1 , 1 6 4 , 4 4}$ it is said of the wind that only its swiftness is seen, not its rüpa (dhrájir ékasya dadrśe ná rüpám). The Satapatha-Brāhmana $(1,1,8,3,8)$ states that "he [i.e., the sun] took to himself the wind's form [rüpa]; whence people hear it, as it were, shaking, but do not see it; and verily, he who knows this, takes away the form of his spiteful enemy." 55 The wind and the bodily breaths are among the principal things called anirukta in the Brähmana texts along with mind, yonder world (of heaven), the whole, brahman (m. \& n.), and Prajāpati. The wind is according to KB 19,2 a perceptible (pratyaksam) rūpa of Prajäpati ${ }^{56}$.

That the Vedic term par excellence for "symbol" should be specifically connected with the sense of sight is not surprising. Turner, for example, reports that "in discussing their symbols with Ndembu, one finds them constantly using the term 'ku-solola 'to make visible' or 'to reveal" "s"57. Such modern terms as "hierophany", "kratophany" and "theophany" applied to religious symbols i.a. by Mircea Eliade ${ }^{58}$ are derived from the Greek verb phaino "to bring to light, cause to appear", hence "manifest, reveal, make known, disclose" "59, which also primarily refers to visible manifestations $^{60}$.

A particularly interesting distinction made by the Vedic ritualists is that between the "outer" ( $b$ ăhya) and "inner" (antara) forms. Modern semiotics defines "symbols" as signs which have no denotata in the phenomenal world but in the mind only ${ }^{61}$. The distinction between extensional and intensional is, however, in semiotics limited to the denotatum ${ }^{61}$, while the Vedic ritualists have extended it even to the "form" of the sign. (We may note here in passing also the exact coincidence of the Vedic term rūpa as "form" with the terminology of modern linguistics and semiotics.) Not only the object symbolized by the symbol but even the form of the symbol itself is unextensional, at least in such cases as that exemplified by the prescription of the Áśvalāyana-Śrautasūtra $(2,3,19)$ : "He should always mentally think upon Prajāpati whenever a silent oblation is performed." $\mathrm{Cf}$.

\footnotetext{
54 Cf. Oldenberg $1919,221 \mathrm{ff}$.

55 Cf. ib. 104.

56 Cf. Renou 1954, 74 f.

57 Turner 1967, 48.
}

${ }^{58}$ Cf. Eliade 437.
${ }^{59}$ Cf. Liddell $1912 \mathrm{f}$.
${ }_{60}$ Cf. Walde 1, $454 \mathrm{f}$.
${ }_{61}$ Cf. Sebeok $246 \mathrm{f}$. 
also SB 1,6,3,27: "What is (uttered) inaudibly that is the rūpa of Prajāpati."

The basic model of thought underlying the use of the term rüpa is, as has been pointed out by Hermann Oldenberg, the distinction between a Platonic sort of idea and its physical manifestations ${ }^{62}$. The latter may be quite numerous, and we have seen above the importance placed on representing a manyformed being symbolically as completely as possible. One method often resorted to in order to do this in the Vedic ritual is to enumerate all the names of the multisided being concerned. Thus we meet with long lists of "wind names", "horse names", "snake names", not to mention the sata-rudriya (cf. TS 2,4,9,1; ĀpŚS 20,5,9; 20,11,1; SB 7,4,1,25ff.; VS 16 , etc. $)^{63}$.

Already in the RS $(3,38,7 ; 7,103,6 ; 10,169,2)$ the term rüpa occurs in connection with the term nāma "name" ${ }^{\prime}$. In Buddhism, näma-rüpau "name and form" stands for the concept of "individuality" or for "individual being", since these immaterial and material principles make up the individual and distinguish it from other individuals ${ }^{65}$. That similar views were prevalent in the Brähmana period can be seen from the myth explaining the structuring of the chaotic universe, told thus in the Taittiriya-Brāhmana $(2,2,7,1)$ : "Prajāpati created the beings. Once created, they were joined closely together [sam-ā-ślișta-, apparently as an undifferentiated mass, chaos being inherent in the creative act]. He entered them with the form [rüpa]. Therefore they say, 'Prajāpati, verily, is the form' [rüpam vai prajäpatir iti]. He entered them with the name [näman]. Therefore they say: 'Prajāpati, verily, is the name.' "'66

The close relation between the concepts of name and form in the Vedic thought is also illustrated by a well known myth related in SB 6,1,3,7 ff. Agni or Fire was born as a boy [kumāra] to the creator god Prajāpati. He cried, because he had no name as yet and was therefore not freed from evil. The text continues: "10. He (Prajāpati) said to him, 'Thou art Rudra'. And because he gave him that name [tan näma], Agni became such-like [or: that form, tad-rüpam], for Rudra is Agni: because he cried [rud-], therefore he is Rudra." The text goes on to describe how Prajāpati on Agni's request gives him seven other names, and each time the relation of the name to his corresponding form is explained ${ }^{67}$.

The very next chapter in the same text is interesting here for several reasons. It shows how a godly power is able to adopt new rüpas at will, and particularly rüpas or forms that at the first sight are perplexing and obscure. It also gives a concrete example of the logic and criteria applied by the Vedic ritualists for the discovery or identification of such a secret rüpa. (The Vedic exegete is here represented by the mythical archetype of the

${ }^{62}$ Cf. Oldenberg 1919, $106 \mathrm{f}$.

${ }^{63}$ Cf. ib. 104.

${ }^{64}$ Cf. ib. 102 f.

${ }^{65}$ Cf. Rhys-Davids 350 a.

${ }^{66} \mathrm{Cf}$. Silburn, Lilian, 58.

${ }_{67} \mathrm{Cf}$. Oldenberg $1919,103 \mathrm{f}$. 
brahmanical offer priest, the creator god Prajāpati.) In SB 6,2,1 we read: "1. Prajāpati set his mind upon Agni's forms. He searched for that boy who had entered into the (aforesaid different) forms. Agni became aware of it-'Surely, Father Prajāpati is searching for me: well, then, let me be suchlike [tad-rüpam] that he knows me not.' 2. He saw those five animals, -the man, the horse, the bull, the ram, and the he-goat. Inasmuch as he saw $[$ paś-] them, they are (called sacrificial) animals [paśu]. 3. He entered into those five animals; he became those five animals. But Prajāpati still searched for him. 4. He saw those five animals ... 5. He considered, 'They are Agni: I will fit them unto mine own self [or: I will make them part of mine own self, imān evātmānam abhisamskaravai]. Even as Agni, when kindled, glares, so their eye glares; even as Agni's smoke rises upwards, so vapour rises from them; even as Agni consumes what is put in him, so they devour; even as Agni's ashes fall down, so do their faeces: they are indeed Agni ...6. . . . He slaughtered them."

As noted above, the rüpa or form is the object of the sight. The perception of a secret rüpa is however conceived as a mental activity. SB 11,2,3,6 states that "it is by mind that one knows "This is form"". Yet, as the above quoted myth shows, this perception is thought of as a sort of vision, for the Brāhmana texts use the verb paś- "to see" of the discovery of secret forms and connections. Vision was considered as the most reliable source of knowledge, as can be seen from SB 1,3,1,27: "for the eye is indeed the truth. If, therefore, two persons were to come disputing with each other and saying, 'I have seen it!' 'I have heard it!' we should believe him who said, 'I have seen it!' and not the other." It is understandable that the Chãndogya-Upanișad $(8,12,5)$ calls the mind (manas) the "divine eye" (daivam cakșus). Asceticism and sacrifice can give the gods and the sages the superhuman ability to see the secret and powerful realities such as holy texts, rituals and identities, which, though existing, are closed from the eyes of the mere mortals (cf. e.g. TS 5,3,5,4) ${ }^{69}$.

In the famous creation hymn of the Rgveda $(10,129,4)$ the "heart" ( $h r d)$ is spoken of as the place where the sages discovered the secret connection $^{70}$. "Heart" takes the place of "mind" as the instrument of conceiving the forms also in the following discussion between Săkalya and Yājnavalkya recorded in $\mathrm{B} \bar{A} U$ 3,9,19-20: "Since you know the quarters of heaven together with their gods and their bases, what divinity have you in this eastern quarter?' 'The sun.' 'That sun-on what is it based?' 'On the eye.' 'And on what is the eye based? [kasmin nu caksuh pratisthitam iti]' 'On appearances, for with eye one sees appearances [rüpeșv iti cakșușa hi rūpāni paśyati].' 'And on what are appearances based?' 'On the heart', he said, 'for with the heart one knows appearances [hrdayena hi rūpāni jānāti], for

68 Cf. ib. 108.

${ }^{69} \mathrm{Cf}$. ib. $222 \mathrm{ff}$; Gonda 1963, $27 \mathrm{ff}$. For the eye as truth cf. also KS 8,3 ; MS $1,8,1 ; 3,6,3$;
Sb 4,2,1,26; AB 1,6.

${ }^{70}$ Cf. also Gonda 1963, 63. 
on the heart alone appearances are based.' 'Quite so, Yajjnavalkya.'"71 This passage introduces us to a term important for the understanding of the magic identifications, namely pratisth $\vec{a}$ "firm foundation, ground, basis, support", and the corresponding verb which consists of the preverb prati "towards, against, upon" and the root sthā- "to stand, stay"; the latter is often used in the causative, with the meaning "to make stand firmly, establish" 72 . The word pratisth $\bar{a}$ is among other things used for the home or native country of a person in the sense of a reliable place where he gets support, where he is free from danger, and to which he always naturally resorts as his own ${ }^{73}$.

The Vedic man appreciated pratistha "foundation" as a benefit and a source of welfare. It was a possession that he sought to acquire for himself by ritual means. He also resorted to the sacrifice when he wished to deprive his enemy of food and foundation, for this meant destruction ${ }^{74}$. Ritual was likewise the instrument to provide the powerful potencies of the universe with strong resting places: it was necessary to prevent them from wandering about arbitrarily (which would mean infringement of the cosmic norms and cause of dangerous disorder), and this could be done by "establishing" them "on their proper places" where they naturally belong. The sacrificial acts, which were supposed to be connected with the cosmic processes, could be used to produce any desired "establishment" of a given person or object ${ }^{75}$.

The knowledge of its foundation thus provides the means for the attainment of the desired object ${ }^{76}$. It is for this reason that Naciketas asks in the Katha-Upanișad $(1,14)$ : "How can the infinite world be attained and what is its foundation (pratișthā)?" 77 An answer to a somewhat similar problem is attempted in AS 17,1,19, where the sage says: "In the non-existent (asat) is the existent (sat) established (pratisthitam); in the existent is being (bhütá) established; being is set in what is to be; what is to be is established in being." Here being and what is to be are said to be established in one another, as indissolubly co-existent ${ }^{78}$. In the creation hymn RS 1,129 this relation is expressed in a different way (verse 4): "the sages have found in their heart the bandhu of the existent in the non-existent." 79

The word bandhu literally means "bond" and is etymologically of the same origin as this English word. In the Brähmana texts it denotes above all the mysterious connection or relation between the entities of this world and the transcendental "ideal" entities of the divine world, which are the foundation and origin of the perceptible things ${ }^{80}$. As Oldenberg has put it,

${ }^{71} \mathrm{Cf}$. Hume 123; Gonda 1954, 24. According to TB $3,10,8,5$, "the eye is based on the heart" (caksur hrdaye pratisthitam).

72 Cf. Gonda 1954, $1 \mathrm{f}$.

${ }^{73} \mathrm{Cf}$. ib. $6 \mathrm{f}$. For the related concepts of ayatana and yoni ("womb"), which cannot be discussed here, cf. ib. 7,10; id. 1969, 1 ff.; Schayer 1925, $279 f$.
${ }^{74}$ Cf. Gonda 1954, $13 \mathrm{ff}$.

${ }^{75} \mathrm{Cf}$. ib. 4,7,11 f., 18,20.

${ }^{76} \mathrm{Cf}$. ib. 17,30 .

77 Cf. ib. 25.

${ }^{78}$ Cf. ib. 27f., 24; Whitney 810 .

${ }^{79}$ Cf. Gonda 1965, 29; id. 1966, 689.

${ }^{80}$ Cf. ib. 689 ; id. $1965,1 \mathrm{ff}$. 
the knowledge of the Brähmanas is above all knowledge about the ban$d h u s^{81}$. We cannot fully understand the nature of the Vedic identifications if we do not take into consideration this term and its connotations ${ }^{82}$. The most important of the latter are its non-technical meanings "kinship tie, connection in blood or through marriage" and hence "relation, relative". In the archaic societies with blood-revenge, levirate marriage etc., "relationship" is much more than the state of having genealogical or other relations to another person; it is "a form of existence in its own right, from which one cannot release oneself", communion in the truest sense of the term, including an intense consciousness of unity. Gonda, from whom I have quoted the preceding sentence, is certainly right in seeing this meaning in the word bandhu used of a mystical identity in SB 2,1,4,17 esa hy evanaduho ban$d h u h$ "for that (fire) is a relation of the ox" 83 .

This passage and interpretation makes it perfectly clear what is meant in SB 13,8,4,6, where the ox is said to be àgneya "of Agni's nature or descent". That the derivative adjective, normally used in patronyms, is here really used to express a magical equation, is secured by the parallel-also to the preceding quotation with bandhu-in SB 7,3,2,1, where the mystic identification has the normal form of a nominal sentence with a predicate noun: agnir eșa yad anadvān "the ox (is) Agni"

\section{Bibliography}
ALB The Adyar library bulletin
AUU Acta Universitatis Upsaliensis. Uppsala
BI Bibliotheca Indica. Calcutta
DRT Disputationes Rheno-Traiectinae. The Hague
HIL A history of Indian literature
HM A handbook of method in cultural anthropology. Ed. R. Naroll, R. Cohen. New York
HOS Harvard Oriental series. Cambridge
IS Indische Studien. Berlin
VIS Vishweshwarananda Indological series. Hoshiarpur

\section{A. Vedic texts}

For translations see $B$ under the name mentioned here in parentheses

AB Aitareya-Brāhmana. Ed. T. Aufrecht. Bonn 1879. (See Keith.) ĀpŚS Āpastamba-Śrauta-Sütra. Ed. R. Garbe 1-3. BI 92, $1882 \mathrm{ff}$. AS Atharvaveda-Samhitā. Ed. D. Sātvalekar. Pardi 1957. (See Whitney.) ĀśvŚS Āśvalāyana-Śrauta-Sütra. Ed. R. Vidyāratna. BI 49, 1874.

${ }^{81}$ Cf. Oldenberg 1919, 4; Gonda 1965, 3.

${ }^{82}$ For bandhu and the closely related term ni-dāna, which cannot be discussed here, $\mathrm{cf}$. especially Gonda 1965, $1 \mathrm{ff}$; Gonda 1969, $63 \mathrm{ff}$.; Renou 1946, $55 \mathrm{ff}$. Cf. also Oldenberg 1919, 117; Schayer 1925, $276 \mathrm{f}$.
83 Cf. Gonda 1965, 22 f.

${ }^{84}$ Cf. ib. 22; Oldenberg 1919, 115 f.; Schayer 1925, 298 f.-For the evidence presented as grounds for the identifications by the Vedic ritualists cf. Oldenberg 1919, $118 \mathrm{ff}$; Schayer $1925,288 \mathrm{ff}$. 
BĀU Bṛhad-Āranyaka-Upaniṣad. Ed. J. Śāstrī, Upaniṣatsañgrahah. Delhi 1970. (See Hume.)

ChU Chāndogya-Upanișad. (As BĀU.)

JB Jaiminīya-Brähmana. Ed. Raghu Vira, Lokesh Chandra. Sarasvati Vihara Series 31. Nagpur 1954.

KapS Kapișthala-Katha-Samhitā. Ed. Raghu Vira. Delhi 1968.

KB Kaușitaki-Brāhmana. Ed. S. Sarma. Verzeichnis der orientalischen Handschriften in Deutschland. Supplementband 9,1. Wiesbaden 1968. (See Keith.)

KS Katha-Samhitāa (Käthaka). Ed. L. v. Schroeder 1-3. Wiesbaden 1970 ff.

KU Kațha-Upanișad. (As BĀU.)

MS Maitrāyañ Samhitā. (As KS.)

PB Pañcaviṇsa-Brāhmana (Tāndya-Mahä-Brāhmana). Ed. with Sāyana's commentary C. Sastri 1-2. The Kashi Sanskrit series 105. Benares 1935 f. (See Caland.)

RS Rgveda-Samhita. Ed. T. Aufrecht 1-2. IS 6-7, $1861 \mathrm{ff}$.

ŚB Śatapatha-Brāhmana (in the Mādhyandina recension). Ed. A. Weber. London 1855. (See Eggeling.)

SVidhB Säma-Vidhäna-Brähmana. Ed. R. Sharma. Kendriya Sanskrit Vidyapeetha Series 1. Tirupati 1964.

TB Taittirìya-Brāhmana. Ed. N. Goḍbole 1-3. Ānandāśrama-samskṛtagranthāvali 37. Poona 1898.

TS Taittirīya-Samhitā. Ed. A. Weber 1-2. IS 11-12. Berlin $1871 \mathrm{f}$.

VS Vājasaneyi-Samhitāa (in the Mādhyandina recension). Ed. A. Weber. London 1852.

\section{B. Modern authors}

Bodewitz, H., 1973, Jaiminìya-Brähmana I, 1-65. Orientalia Rheno-Traiectina 17. Leiden.

Caland, W., 1931, Pañcavimśa-Brähmana. BI 255.

Collinder, B., 1962, Les origines du structuralisme. AUU. Acta Societatis Linguisticae Upsaliensis. N. S. 1,1 .

Diehl, C., 1956, Instrument and purpose. Diss. Lund.

Durkheim, É., 1976, The elementary forms of the religious life. London.

Eggeling, J., 1882 ff., The Śatapatha-Brähmana according to the text of the Mádhyandina school translated 1-5. Sacred Books of the East 12, 26, 41, 43, 44. Oxford.

Eliade, M., 1958, Patterns in comparative religion. London.

Frazer, J., 1957, The golden bough. London.

Gonda, J., 1954, Pratișthā. Samiñāvyākaranam. Studia Indologica Internationalia 1. Poona.

- 1955, Reflections on sarva- in Vedic texts. Indian Linguistics 16.

- 1957, Some observations on the relations between "gods" and powers in the $V e d a$, a propos of the phrase sūnuh sahasah. DRT 1.

- 1960, Die Religionen Indiens 1. Die Religionen der Menschheit 11. Stuttgart.

- 1963, The vision of the Vedic poets. DRT 8.

- 1965, Bandhu- in the Brāhmaña-s. Brahmavidyä: ALB 29.

- 1966, De kosmogonie van Rgveda 10, 129. Tijdschrift voor Philosophie 28.

- 1969, Āyatana-. Brahmavidyā: ALB 33.

- 1975, Vedic literature (Samhitās and Brähmanas). HIL 1,1. Wiesbaden.

- 1977, Ritual Sütras. HIL 1,2. Wiesbaden.

Gren-Eklund, Gunilla, 1978, A study of nominal sentences in the oldest Upanisads. Diss. AUU. Studia Indoeuropaea Upsaliensia 3. Uppsala. 
Hillebrandt, A., 1897, Ritual-Litteratur, vedische Opfer und Zauber. Grundriss der Indo-Arischen Philologie und Altertumskunde 3,2. Strassburg.

Hubert, H., Mauss, M., 1964, Sacrifice: its nature and function. London.

Hume, R., 1931, The thirteen principal Upanishads translated. Oxford.

Keith, B., 1920, Rigveda Brahmanas translated. HOS. 25.

Lévi, S., 1898, La doctrine du sacrifice dans les Brähmaṇas. Bibliothèque de 1'École des Hautes Études. Sciences religieuses 11. Paris.

Liddell, H., Scott, R., 1940, A Greek-English Lexicon. Oxford.

Macdonell, A., 1929, A practical Sanskrit dictionary. Oxford.

Middleton, J., 1970, The religious system. HM.

Monier-Williams, M., 1899, A Sanskrit-English dictionary. Oxford.

Mylius, K., 1968, Die Identifikationen der Metren in der Literatur des Rgveda. Wissenschaftliche Zeitschrift der Karl-Marx-Universität Leipzig. Gesellschaftsund Sprachwissenschaftliche Reihe 17.

- 1976, Die vedischen Identifikationen am Beispiel des Kaușītaki-Brāhmaṇa. Klio 58.

O'Flaherty, Wendy,1973, Asceticismanderoticism in themythology of Siva. London.

Oldenberg, H., 1915, Die Lehre der Upanishaden und die Anfänge des Buddhismus. Göttingen.

- 1917, Zur Geschichte der altindischen Prosa. Abhandlungen der Kgl. Gesellschaft der Wissenschaften zu Göttingen. Phil.-hist. K1. N. F. 16,6. Berlin.

- 1919, Vorwissenschaftliche Wissenschaft. Göttingen.

Parpola, A., 1968, The Śrautasūtras of Lätyāyana and Drähyāyana and their commentaries 1,1 . Societas Scientiarum Fennica. Commentationes Humanarum Litterarum 42,2. Helsinki.

- 1976, The encounter of religions in India, 2000-1000 в.C. Temenos 12.

Pike, K., 1964, Towards a theory of the structure of human behavior. Language in culture and society. Ed. D. Hymes. New York.

Renou, L., 1946, 'Connexion' en védique, 'cause' en bouddhique. A volume of Indological studies presented to Dr. C. Kunhan Raja. Madras.

Renou, L., Silburn, Lilian, 1954, Nírukta and Ánirukta in Vedic. Sarüpa-Bhāratī: The homage of indology, Dr. Lakshman Sarup memorial volume. Ed. J. Agrawal, B. Shastri. VIS 6.

Rhys-Davids, T., Stede, W., 1925, The Pali Text Society's Pali-English dictionary. London.

Schayer, S., 1925, Die Struktur der magischen Weltanschauung nach dem A tharvaVeda und den Brähmaṇa-Texten. Zeitschrift für Buddhismus 6.

- 1925 a, Über die Bedeutung des Wortes upanișad. Rocznik Orjentalistyczny 3.

Schroeder, L. v., 1887, Indiens Literatur und Cultur in historischer Entwicklung. Leipzig.

Sebeok, T., 1974, Semiotics. Current trends in linguistics 12. The Hague.

Silburn, Lilian, 1955, Instant et cause. Diss. Paris.

Staal, F., 1972, A reader on the Sanskrit grammarians. Studies in linguistics 1. Cambridge.

Turner, V., 1967, The forest of symbols. Ithaca.

- 1969, The ritual process. London.

Vishva Bandhu, 1966, Brāhmanic Citations. VIS 38.

Walde, A., Hofmann, J., 1938, Lateinisches etymologisches Wörterbuch 1-2. Indogermanische Bibliothek 1,2. Heidelberg.

Werner, O., Fenton, Joann, 1970, Method and theory in ethnoscience and ethnoepistemology. HM.

Whitney, W., 1905, Atharva-Veda-Samhità translated 1-2. HOS 7-8. 